\title{
Bacillus sp. probiotic supplementation diminish the Escherichia coli F4ac infection in susceptible weaned pigs by influencing the intestinal immune response, intestinal microbiota and blood metabolomics
}

Diana Luise ${ }^{1}$, Micol Bertocchi ${ }^{2}$, Vincenzo Motta ${ }^{1}$, Chiara Salvarani ${ }^{1}$, Paolo Bosi ${ }^{1}$, Andrea Luppi ${ }^{3}$, Flaminia Fanelli ${ }^{4}$, Maurizio Mazzoni ${ }^{5}$, Ivonne Archetti ${ }^{3}$, Giuseppe Maiorano ${ }^{2}$, Bea K. K. Nielsen ${ }^{6}$ and Paolo Trevisi ${ }^{1 *}$ (D)

\begin{abstract}
Background: Probiosis is considered a potential strategy to reduce antibiotics use and prevent postweaning diarrhea (PWD). This study investigated the effect of Bacillus amyloliquefaciens DSM25840 or Bacillus subtilis DSM25841 supplementation on growth, health, immunity, intestinal functionality and microbial profile of post-weaning pigs after enterotoxigenic E. coli (ETEC) F4 challenge.
\end{abstract}

Methods: Sixty-four post-weaning piglets $(7748 \mathrm{~g} \pm 643 \mathrm{~g})$ were randomly allocated to four groups: control basal diet (CO); $\mathrm{CO}+1.28 \times 10^{6} \mathrm{CFU} / \mathrm{g}$ of B. amyloliquefaciens (BAA); $\mathrm{CO}+1.28 \times 10^{6} \mathrm{CFU} / \mathrm{g}$ feed of B. subtilis (BAS); CO $+1 \mathrm{~g}$ colistin/ $\mathrm{kg}$ of feed (AB). At day (d) 7, animals were challenged with $10^{5} \mathrm{CFU} / \mathrm{mL}$ of ETEC F4ac O149 and then followed for fecal score and performance until d 21. Blood was collected at $d 6, d 12$ and $d 21$ for immunoglobulins, at $d 8$ for acute phase proteins, at d 8 and d 21 for metabolomics analysis. Jejunum was sampled for morphometry, quantification of apoptosis, cell proliferation, neutral and acid mucine and IgA secretory cells, and microarray analysis at d 21. Jejunum and cecum contents were collected for microbiota at d 21.

Results: $A B$ and BAS reduced the fecal score impairment compared to $C O(P<0.05)$ at $d 14$. Body weight $(B W)$, average daily weight gain (ADWG), average daily feed intake (ADFI) and gain to feed ratio (G:F) did not differ between Bacillus groups and CO. AB improved BW at d 7, d 14 and $d 21$, ADWG ADFl and G.F from d 0 to $d 7(P<0.05)$. At $d 8$, CO had higher plasma arginine, lysine, ornithine, glycine, serine and threonine than other groups, and higher haptoglobin than $A B$ $(P<0.05)$. At $d 21$, CO had lower blood glycine, glutamine and IgA than BAS. Morphology, cells apoptosis and mucins did not differ. BAS and AB increased the villus mitotic index. Transcriptome profile of BAS and AB were more similar than CO. Gene sets related to adaptive immune response were enriched in BAA, BAS and AB. CO had enriched gene set for nuclear structure and RNA processing. CO had a trend of higher Enterobacteriaceae in cecum than the other groups $(P=0.06)$.

Conclusion: Bacillus subtilis DSM25841 treatment may reduce ETEC F4ac infection in weaned piglets, decreasing diarrhea and influencing mucosal transcriptomic profile.

Keywords: Bacillus amyloliquefaciens, Bacillus subtilis, Diarrhea, ETEC, Gut microbiota, Post-weaning, Transcriptomics

\footnotetext{
*Correspondence: paolo.trevisi@unibo.it

${ }^{1}$ Department of Agricultural and Food Sciences, University of Bologna, Viale

G. Fanin 46, 40127 Bologna, Italy

Full list of author information is available at the end of the article
}

(c) The Author(s). 2019 Open Access This article is distributed under the terms of the Creative Commons Attribution 4.0 International License (http://creativecommons.org/licenses/by/4.0/), which permits unrestricted use, distribution, and

reproduction in any medium, provided you give appropriate credit to the original author(s) and the source, provide a link to the Creative Commons license, and indicate if changes were made. The Creative Commons Public Domain Dedication waiver (http://creativecommons.org/publicdomain/zero/1.0/) applies to the data made available in this article, unless otherwise stated. 


\section{Introduction}

Weaning remains a critical phase in pig production and it is related to the PWDS that cause digestive disorders and in some cases mortality. The enterotoxigenic Escherichia coli (ETEC) that express the F4 ac fimbria is considered one of the main etiological pathogens associated with post-weaning diarrhea syndrome (PWDS) in piglets [1].

Antibiotics have long been added in the starter diet of piglets, however, their continued use is an ongoing growing concern for the occurrence of antimicrobial resistance. Therefore, the study of alternatives to antibiotics is important for the feed industry, for pig farmers and stakeholders to develop a more sustainable production system less dependent on antibiotic use. Among the alternatives, probiotic bacteria have been investigated for their preventive role in contrasting the ETEC infection by the modulation of the gastrointestinal microbiota, favouring the gut eubiosis [2-4], or by their potential immunomodulatory effect on the intestinal immune response [5, 6]. Among probiotics, those of Bacillus group in sensu lato are considered promising beneficial bacteria for their capacity to produce antimicrobial substances such as bacteriocins, peptides and lipopeptides [7]. However, different strains from one species can have very different properties [8]. Recently, Bacillus amyloliquefaciens DSM25840 (B. amyloliquefaciens) and Bacillus subtilis DSM25841 (B. subtilis) have been ascribed as potential probiotic for pigs based on extensive in vitro screening [8] and have shown positive effects in production trials in piglets [9]. While no influence on nursery piglets' performance supplemented whit a mixture of $B$. licheniformis, $B$. subtilis and $B$. amyloliquefaeceans spores has been observed by Poulsen et al. [10], other studies have shown that also other strains of $B$. subtilis and $B$. amyloliquefaciens exhibited promising activity against pathogenic bacteria [7]. In pigs, the administration of B. amyloliquefaciens increased body weight, reduced diarrhea incidence and enhanced the antioxidant status of weaned piglets $[11,12]$. Furthermore, it showed an improvement of the mucosal morphology, a decrease of tumour necrosis factor alpha (TNF $\alpha$ ) level and a beneficial regulation of the microbiota in the small intestine of intra-uterine growth retardation (IUGR) piglets [13]. B. subtilis supplementation has been tested as probiotic giving promising results in sows and suckling piglets [14], in growing pigs [15] and in growing pigs in a mix with B. licheniformis [16] and in weaned [17] and suckling [18] piglets.

Although previous studies demonstrated the probiotic role of Bacillus strains, only a few studies investigated the effect of Bacillus strains against diarrhea caused by ETEC in weaned piglets $[19,20]$. Therefore, the aims of the present study were to evaluate the ability of dietary administration of B. amyloliquefaciens DSM25840 or B. subtilis DSM25841 in counteracting the ETEC F4ac infection of weaned piglets and to investigate the mode of action of these specific Bacillus strains on piglets' health and intestinal functionality.

\section{Material and methods}

\section{Animals and experimental desing}

In total 64 piglets were selected from a farm where ETEC F4ac infection was frequently evidenced and based on the polymorphism for the mucin4 gene [21], in order to obtain ETEC F4ac susceptible pigs [1]. At weaning [24 \pm 2 days of age; initial body weight $(\mathrm{BW}) 7.75 \mathrm{~kg} \pm$ $0.64 \mathrm{~kg}](\mathrm{d} 0)$ animals were moved to the experimental facility of the Department of Agricultural and Food Science (DISTAL) - University of Bologna. Pigs were housed in individual cages with a mesh floor except for the first 3 days of the trial when pigs were kept in groups of two animals to stimulate the feed intake immediately after weaning. Room temperature was kept controlled at $30^{\circ} \mathrm{C}$ at the beginning and $25^{\circ} \mathrm{C}$ at the end of the experiment, with a $1{ }^{\circ} \mathrm{C}$ decrease every 3 days. Infrared lamps were located above the piglets for the first 7 days post-weaning. The piglets had free access to feed and water throughout the experimental period; feed was ad libitum supplied in a dry feeder. At $\mathrm{d} 0$ pigs were assigned to four different groups (16 piglets/group) balanced by litter and BW. The groups were assigned to 1 of the 4 treatments: i) Control group (CO) fed with a basal diet (Table 1); ii) (BAA): $\mathrm{CO}+1.28 \times 10^{6} \mathrm{CFU} / \mathrm{g}$ feed of B. amyloliquefaciens DSM25840; iii) (BAS): $\mathrm{CO}+$ $1.28 \times 10^{6} \mathrm{CFU} / \mathrm{g}$ feed of $B$. subtilis DSM25841; iv) antibiotic group (AB): $\mathrm{CO}+1 \mathrm{~g}$ colistin $/ \mathrm{kg}$ of feed.

On $\mathrm{d} 7$, all pigs were orally dosed with $1.5 \mathrm{~mL}$ suspension containing $10^{5} \mathrm{CFU}$ of ETEC F4ac O149 per $\mathrm{mL}$. On d 8, 24 h after the ETEC infection, 24 animals (6 animals per group, randomly chosen), were deeply anaesthetized with sodium thiopental $(10 \mathrm{mg} / \mathrm{kg} \mathrm{BW})$ and sacrificed by an intracardiac injection of Tanax $(0.5 \mathrm{~mL} /$ $\mathrm{kg} \mathrm{BW})$. The remained piglets were kept and followed until d 21 and then sacrificed using the same procedure.

\section{Sampling and data collection}

Body weight was recorded weekly from the beginning of the trial $(\mathrm{d}$ 0) to the slaughtering $(\mathrm{d} 21)$. In the first 2 days, feed intake was measured for the groups of two pigs. From d 3, when pigs started to be individually penned, individual feed intake of each pig was registered every day.

For each pig, the severity of diarrhea was recorded daily from d 4 to $\mathrm{d} 21$ using a 5-point fecal score system: $1=$ hard; $2=$ firm; $3=$ soft (moist stool); $4=$ soft (unformed stool); $5=$ watery faeces $[1,23]$. Pigs were excluded from the trial due to a severe impairment of 
Table 1 Ingredient and calculated composition of the basal diet ( $\mathrm{g} / \mathrm{kg}$ as fed basis)

\begin{tabular}{|c|c|}
\hline Items & Content \\
\hline \multicolumn{2}{|l|}{ Ingredients, \% } \\
\hline Corn & 27.00 \\
\hline Barley & 25.10 \\
\hline Biscuit by-product & 20.00 \\
\hline Rice protein concentrate & 4.20 \\
\hline Milk whey & 4.00 \\
\hline Wheat middlings & 4.00 \\
\hline Soybean meal, 50\% CP & 3.00 \\
\hline Wheat gluten & 2.50 \\
\hline Soy oil & 3.50 \\
\hline Brewer's yeast & 2.00 \\
\hline Potato, protein concentrate & 1.50 \\
\hline Dicalcium phosphate & 1.00 \\
\hline Carrob pulp & 1.00 \\
\hline Miner-vitamin premix & 0.50 \\
\hline Calcium carbonate & 0.50 \\
\hline Salt & 0.20 \\
\hline \multicolumn{2}{|l|}{ Calculated chemical composition } \\
\hline Crude protein, \% & 16.50 \\
\hline Crude fat, $\%$ & 5.80 \\
\hline Crude fibre, \% & 3.12 \\
\hline Ash, \% & 4.22 \\
\hline $\mathrm{Ca}, \%$ & 0.60 \\
\hline$P, \%$ & 0.50 \\
\hline $\mathrm{NaCl}, \%$ & 0.38 \\
\hline $\mathrm{Cu}, \mathrm{mg}$ & 150 \\
\hline $\mathrm{Zn}, \mathrm{mg}$ & 135 \\
\hline Lysine,\% & 1.20 \\
\hline Met + Cys, \% & 0.70 \\
\hline $\mathrm{ME}, \mathrm{kcal} / \mathrm{kg}$ & 3144 \\
\hline
\end{tabular}

ME Metabolic energy, the values were estimated by the EvaPig ${ }^{\circledR}$ software [22] using information from the INRA-AFZ tables of feedstuff composition (INRA-AFZ, 2004)

health status when a fecal score of 5 was recorded for more than 4 continuous days and pigs showed low feed intake for the same period.

Plasma samples were individually collected at $\mathrm{d} 8$ and $\mathrm{d}$ 21 using a K3 EDTA (Vacutest Kima Srl, Arzergrande PD Italy) collection tube by venipuncture of vena cava. To obtain plasma, blood samples were centrifuged at $3,000 \times g$ for $10 \mathrm{~min}$ at $4{ }^{\circ} \mathrm{C}$. Plasma samples were stored at $-80^{\circ} \mathrm{C}$ until further targeted metabolomics profile analysis [24].

Serum samples were individually collected by venipuncture of vena cava at d 6 (before challenge), d 12 and d 21, using a collection tube without anticoagulant. To obtain serum, blood was incubated at room temperature for $2 \mathrm{~h}$, then centrifuged at $3,000 \times g$ for $10 \mathrm{~min}$. The serum was incubated at $56^{\circ} \mathrm{C}$ for $30 \mathrm{~min}$ and finally stored at $-20^{\circ} \mathrm{C}$ for immunoglobulins and acute phase proteins analysis.

At d 21, after animals' sacrifice, the gastrointestinal tract (GIT) was immediately removed. The mucosa from the distal part of jejunum ( $75 \%$ of the small intestine length) was gently scraped and snap-frozen in liquid nitrogen and then preserved at $-80^{\circ} \mathrm{C}$ for microarray analysis. For microbiota analysis, the intestinal content from the same jejunum site and from cecum was immediately collected into a sterile tube, snap-frozen in liquid nitrogen and then preserved at $-80^{\circ} \mathrm{C}$. Furthermore, an additional intestinal segment from the same jejunum section was collected for morphometric, histology and immunohistochemistry analysis. For the morphometric analysis, tissue samples were fixed overnight in 10\% neutral buffered formalin and embedded in paraffin. The sections were stained with hematoxylin-eosin for the morphometric evaluation.

\section{Plasma targeted metabolomics analysis}

Plasma metabolites were measured using the Biocrates AbsoluteIDQTM p180 Kit (Biocrates Life Science AG, Innsbruck, Austria) that allows to quantify a panel of 188 compounds, including 40 acylcarnitines, 21 amino acids, 21 biogenic amines, 90 glycerophospholipids [14 lysophosphatidylcholines (lysoPC) and 76 phosphatidylcholines (PC)], 15 sphingolipids and hexoses (sum of hexoses, including glucose). The kit was processed according to manufacturer instructions and analysed on the Serie 200 high-pressure liquid chromatography system by Perkin Elmer (Waltham, MA) coupled with the API 4000 QTRAP by AB Sciex (Foster City, CA, USA). Amino acid and biogenic amine classes were analysed by liquid chromatography-tandem mass spectrometry (LCMS/MS). Acylcarnitines, phospho- and sphingolipids and hexose were analysed by flow injection analysis (FIA) - MS/MS. Instrumental data were acquired and processed by Analyst 1.6.3, whereas data quantitation and validation were performed by MetIDQ-5.5.4-dB100Boron-2623 software. Results were exported in micromolar unit $(\mu \mathrm{mol} / \mathrm{L})$.

\section{Serum immunoglobulins and acute phase protein determination}

Serum IgA, IgG and IgM were quantified on samples collected at d 6, d 12 and d 21. Samples were diluted 1:6,400 for IgA, 1:500,000 for IgG and 1:50,000 for IgM. Determination of total IgA in serum was carried out by ELISA, using Pig Immunoglobulin Reference Serum (Bethyl Laboratories, Montgomery, TX) as the specific antibody for the standard curve, Goat anti-Pig IgA-HRP coniugate 
(Bethyl Laboratories) as a secondary antibody, and 2,2'azino-bis (3-ethylbenzthiazoline-6-sulfonic acid; Roche Diagnostics, San Francisco, CA) for chromogenic detection as described by Bosi et al. [25]. Porcine specific commercial ELISA kits were used to analyse serum concentration of total IgM, IgG (Bethyl Laboratories, Montgomery, TX) according to the manufacturer's instructions. Serum acute protein determination was carried out on the samples on d 8. Haptoglobin (Hp), Serum Amyloid A (SAA) and C-Reactive Protein (CRP) were determined using porcine specific commercial ELISA kits (Tridelta Development Limited, Maynooth, County Kildare, Ireland) according to the manufacturer's instructions. Samples were diluted 1:3 for $\mathrm{Hp}, 1: 50$ for SAA and 1:100 for CRP. IgM, IgG and Hp concentrations were expressed as milligram per millilitre $(\mathrm{mg} / \mathrm{mL})$; SAA and CRP were expressed as milligram per litre $(\mathrm{mg} / \mathrm{L})$.

\section{Microbiota analysis}

Total bacterial DNA was extracted using the FastDNA SPIN Kit for Soil (MP Biomedicals, Santa Ana, CA, USA) following the manufacturer's instructions. The library formation and sequencing of the 16S rRNA gene were performed with $\mathrm{MiSeq}^{\bullet}$ Reagent Kit V3-V4 on MiSeq-Illumina ${ }^{\circ}$ platform. Generated sequences were analysed using the subsampled open reference operational taxonomic unit (OTU) strategy with default settings in QIIME (v1.9.1). The paired-end reads were merged and demultiplexed. Subsampled open-reference OTU-picking was performed using UCLUST with $97 \%$ sequence similarity. Representative sequences were chimera checked using Blast_fragments approach with default settings and taxonomy assigned against the Greengenes database V13_8 using the UCLUST method with a $90 \%$ confidence threshold. The singletons and OTUs with relative abundance across all samples below $0.005 \%$ were excluded as recommended by Bokulich et al. [26]. The samples that reported low sequencing yield (less than 5,000 reads after quality check) were excluded from the analysis.

\section{RNA isolation and microarray analysis}

For microarray analysis, 6 out 10 pigs per group were randomly selected. Total mRNA was isolated from 50 $\mathrm{mg}$ of frozen distal jejunum mucosa according to the Takara Fast Pure kit (Takara Bio, Japan) protocol. The purity and concentration of the total RNA were checked using the Nanodrop ND 1000 (Nanodrop Technologies, USA), while RNA integrity was assessed by Agilent Bioanalyzer 2100 (Agilent Technologies, USA). Total mRNA was hybridized on Affymetrix Porcine Gene 1.1 ST array strips. Hybridized arrays were scanned on a GeneAtlas imaging station (Affymetrix, Santa Clara, CA, USA). Performance quality tests of the arrays including the labelling, hybridization, scanning and background signals by a Robust Multichip Analysis were performed on the CEL files using the Affymetrix Expression Console. The Affymetrix Transcripts ID's, in general, characterized each one by several exonic sequences, were associated with 13,494 human gene names, based on Sus scrofa Ensembl (release 83, www.ensembl.org).

\section{Morphometric, histochemical and immunohistochemistry analysis}

Paraffin sections were deparaffinised in xylene and stained with haematoxylin-eosin. The height and width of 10 villi and the depth and width of 10 crypts (randomly selected) were measured for each sample. The mucosal-to-serosal amplification ratio $(M)$ was calculated as following: $M=$ (villous surface + unit bottom villous bottom)/unit bottom, where villous surface $=\pi \times$ (villous length $\times$ villous width), unit bottom $=\pi \times$ (villous width $/ 2+$ crypt width $/ 2)^{2}$ and villous bottom $=\pi \times$ (villous width $/ 2)^{2}$, according by Kisielinski et al. [27]. Wellorientated intestinal tissue sections were used to count the goblet cells per intestine villi or crypt of each piglet.

The combination of the alcian blue (ALB) $\mathrm{pH} 2.5$ and the periodic acid-Schiff method (PAS) techniques were used as a means of distinguishing acid mucins from neutral mucins respectively [28]. Briefly, the ALB at a pH of 2.5 will stain all acid mucins deep blue, while the PAS technique stain the neutral mucins bright magenta. The cells that contain both neutral and acidic mucins may demonstrate a purple coloration. Mean number of PAS, ALB and combined PAS/ALB-stained goblet cells per villus and crypts were evaluated by measuring 10 villi and 10 crypts.

Paraffin sections $(7 \mu \mathrm{m}$ thick), mounted on poly- $L$-lysine-coated slides, were processed for immunohistochemistry to evaluating the cellular proliferation (cell proliferation antigen Ki67) and the IgA secreting cells. In addition, to determine the apoptotic cells, the Apoptosis Detection Kit (ApopTag ${ }^{\circ}$ Plus peroxidase in situ kit, S701, Millipore, Temecula, CA, USA) was used.

Briefly, paraffin sections were deparaffinized and rehydrated; to unmask the antigenic sites, the slides were heated in sodium citrate buffer ( $\mathrm{pH}$ 6.0) in a microwave. Endogenous peroxidase was blocked with $1 \%$ aqueous hydrogen peroxide solution for $30 \mathrm{~min}$ at RT and subsequently incubated in PBS containing 10\% normal goat serum to prevent nonspecific binding of the antibodies. The sections were then incubated overnight at $4{ }^{\circ} \mathrm{C}$ with the following antibodies: mouse anti-Ki67 antibody diluted 1:700 (AB15580, Abcam, UK) and goat anti-porcine IgA 1:4000 (NB724, Novus Biological Abingdon, UK). After washing, sections were incubated for $1 \mathrm{~h}$ with the appropriate biotin-conjugated secondary antibody [goat anti-mouse IgG and horse anti-goat IgG, both diluted 1:500 (Vector)] and then treated with $\mathrm{ABC}$ 
complex (Vector elite kit, Vector Laboratories). The immune reactions were visualized applying a 3,3'-diaminobenzidine chromogen solution (Vector DAB kit, Vector Laboratories). IgA quantitation was calculated according to the method of Waly et al. [29]: five appropriate areas were randomly chosen for each piglet; the areas were delineated on the computer screen, excluding the epithelium, large blood vessel and artefacts; positively stained cells within each region were counted. Results were expressed as positive cells per $10,000 \mu \mathrm{m}^{2}$.

\section{Statistical analysis and data processing}

For mortality data, Fisher's exact test was performed testing separately BAA, BAS and AB against CO. Data of performances, fecal score, Igs, acute phase proteins, plasma metabolites and morphometric and immune histological data were analysed by analysis of variance using the GLM procedure of SAS (SAS Inst., inc., Cary, $\mathrm{NC}$ ) considering the treatment and the origin litter as factors. Sex was initially included as a fixed factor but resulted always not significant and was dropped off the final model. The available degrees of freedom for the treatment were used for testing separately BAA, BAS and $\mathrm{AB}$ against $\mathrm{CO}$. Before statistical analysis, metabolomics data were imported into the MetaboAnalyst 3.0 software [30] where data integrity was checked. Metabolites showing more than $50 \%$ of missing values were removed. Data normalization were performed against the median of metabolite concentrations measured for the treatment group, then data were log transformed and mean-central scaled. $P$-values were corrected for false discovery rate (FDR). $P$-value $<0.05$ was considered as significant and $P$-value $<0.1$ was considered a trend of significance.

Biostatistics on OTUs table were performed using phyloSeq [31], Vegan [32] packages in R software (v.3.3.0). The richness and alpha diversity indices (Shannon and Chao indices) were calculated on the raw data matrix while beta diversity ordination (Bray-Curtis distance matrix) were calculated after rarefaction correction.

Alpha diversity indices were compared with multivariate ANOVA testing litters and the treatment as explanatory variables. The treatment differences in beta diversity were explored using permutational manova (Adonis procedure) on the Bray-Curtis distance matrix. Then, in order to evaluate differences in the most abundant family among groups the Wilcoxon signed-rank test was performed. $P$ values were corrected for FDR correction. $P$-value $<0.05$ was considered as significant and $P$-value $<0.1$ was considered a trend of significance.

On processed gene expression values, an exploratory functional analysis was performed using the Gene Set Enrichment Analysis (GSEA) approach. The GSEA approach is based on gene sets, defined as groups of genes with common biological function, chromosomal location, or regulation [33]. The GSEA analysis was carried out on Gene Set Enrichment Analysis software, using the C5.v5.1 catalogue of gene sets (based on Gene Ontology) from Molecular Signatures Database v3.1 (http://software.broadinstitute.org/gsea/msigdb/index.jsp). The normalized enrichment score (NES) was calculated for each gene set. BAA, BAS and $\mathrm{AB}$ treatments were separately tested against $\mathrm{CO}$ and statistical significance was considered when false discovery rate (FDR) $\%<25$ and $P$-values of NES $<0.05$ [34]. Enrichment score $P$-values were estimated using a gene set-based permutation test procedure following the GSEA recommended pipeline.

The common up and down-regulated gene sets among $\mathrm{AB}, \mathrm{BAA}$ and $\mathrm{BAS}$ in contrast with the $\mathrm{CO}$ group were visualized using a Venn diagram performed using Venny software (http:// bioinfogp.cnb.csic.es/tools/venny/).

\section{Results}

One subject of the $\mathrm{AB}$ group was excluded from the trial because injured during the transport.

\section{Monitoring of health status}

No significant differences in the number of piglets excluded from the trial for severe impairment of health status were observed between Bacillus dietary supplementation groups and $\mathrm{CO}$. The number of excluded piglets after the challenge was, however, higher in the $\mathrm{CO}$ group. In the $\mathrm{AB}$ group, all pigs remained healthy during the entire experimental period. In details: 2 piglets from BAA group, 1 piglet from BAS group, and 1 piglet from $\mathrm{CO}$ group were excluded during the first week, before ETEC F4 challenge. Twenty-four hours after the infection (d 8), 2 piglets of the BAA group and 1 piglet of the $\mathrm{CO}$ group were excluded. During the period from d 10 to $\mathrm{d} 12,3$ additional pigs of $\mathrm{CO}$ group were excluded. The $\mathrm{CO}$ group had a higher fecal score than the $\mathrm{AB}$ group $(P \leq 0.01)$, while BAS tended to reduce the fecal score at $\mathrm{d} 14$ compared to $\mathrm{CO}(P=0.06)$. No differences in fecal score were observed between $\mathrm{CO}$ and BAA groups (Table 2).

\section{Performances}

No differences for BW and ADWG at d 7, d 14 and d 21 were observed for the BAA and the BAS groups compared to the $\mathrm{CO}$ group (Table 3). The AB group had higher BW at d 7, d 14 and $\mathrm{d} 21$ than the CO group did $(P \leq 0.05)$. Moreover, the AB group had higher ADWG than the $\mathrm{CO}$ group during the first-week post-weaning (d 0 to $\mathrm{d} 7)(P<0.001)$, and a trend of higher ADWG was observed in the post-challenge period $(\mathrm{d} 8-\mathrm{d} 21)$ in the $\mathrm{AB}$ group than in the $\mathrm{CO}$ group $(P=0.09)$. 
Table 2 Effect of dietary supplementation of Bacillus amyloliquefaciens DSM25840 and Bacillus subtilis DSM25841 on fecal score and days of diarrhea of weaned pigs challenged with Escherichia coli F4ac

\begin{tabular}{|c|c|c|c|c|c|c|c|c|}
\hline \multirow[t]{2}{*}{ Items } & \multicolumn{4}{|c|}{ Treatments $^{\mathrm{a}}$} & \multirow[t]{2}{*}{ SEM } & \multicolumn{3}{|l|}{$P$-value } \\
\hline & BAA & BAS & $A B$ & $\mathrm{CO}$ & & BAA vs. CO & BAS vs. CO & $A B$ vs. $C O$ \\
\hline \multicolumn{9}{|l|}{ Fecal score } \\
\hline Day $6^{b}$ & 3.75 & 3.72 & 1.97 & 3.63 & 0.27 & 0.45 & 0.54 & $<0.001$ \\
\hline Day $8^{c}$ & 3.66 & 3.44 & 1.9 & 3.38 & 0.28 & 0.28 & 0.68 & $<0.001$ \\
\hline Day $14^{d}$ & 3 & 2.4 & 1.78 & 3.4 & 0.38 & 0.4 & 0.06 & 0.01 \\
\hline Day $21^{d}$ & 3.15 & 2.6 & 1.89 & 3.4 & 0.34 & 0.56 & 0.11 & 0.01 \\
\hline
\end{tabular}

aAA B. amyloliquefaciens DSM25840, BAS B. subtilis DSM25841, AB Antibiotic, CO Control

${ }^{b}$ Number of animals was 16 for BAA, BAS and $C O$ groups; 15 for AB group

'Number of animals was: 14 for BAA; 15 for BAS, $A B$ and $C O$.

${ }^{d}$ Number of animals was 6 for $B A A ; 9$ for $B A S ; 10$ for $A B ; 6$ for $C O$

No differences for ADFI were observed for BAA and BAS groups compared to the $\mathrm{CO}$ group. The $\mathrm{AB}$ group had higher ADFI than the $\mathrm{CO}$ group during first-week post-weaning ( $\mathrm{d} 0$ to $\mathrm{d} 7)(P<0.001)$. A trend of higher ADFI was observed in the $A B$ group than in the $C O$ group for the period $\mathrm{d} 8-\mathrm{d} 14$ and for the global period. No differences for G:F were observed for the BAS group compared to the $\mathrm{CO}$ group. The $\mathrm{AB}$ group had higher G:F than $\mathrm{CO}$ group $(P<0.001)$ during first-week postweaning ( $\mathrm{d} 0$ to $\mathrm{d} 7$ ) and a trend of higher G:F was

Table 3 Effect of dietary supplementation of Bacillus amyloliquefaciens DSM25840 and Bacillus subtilis DSM25841 on growth performance of weaned pigs challenged with Escherichia coli F4ac

\begin{tabular}{|c|c|c|c|c|c|c|c|c|}
\hline \multirow[t]{2}{*}{ Items } & \multicolumn{4}{|c|}{ Treatments $^{a}$} & \multirow[t]{2}{*}{ SEM } & \multicolumn{3}{|l|}{$P$-value } \\
\hline & $\mathrm{BAA}$ & BAS & $A B$ & $\mathrm{CO}$ & & BAA vs. CO & BAS vs. CO & $A B$ vs. $C O$ \\
\hline \multicolumn{9}{|l|}{ Body weight, g } \\
\hline $\mid$ nitial ${ }^{b}$ & 7779 & 7789 & 7869 & 7619 & 266 & 0.60 & 0.60 & 0.49 \\
\hline Day $7^{c}$ & 7638 & 7581 & 8208 & 7356 & 308 & 0.64 & 0.60 & 0.02 \\
\hline Day $14^{d}$ & 8912 & 8279 & 9201 & 8370 & 350 & 0.33 & 0.92 & 0.05 \\
\hline Final (day 21) & 10855 & 10036 & 11319 & 10102 & 549 & 0.28 & 0.94 & 0.03 \\
\hline \multicolumn{9}{|l|}{ Average daily live weight gain, g/d } \\
\hline Day 0 - day $7^{c}$ & -27.6 & -41.6 & 48.5 & -62.3 & 28.7 & 0.61 & 0.99 & $<0.001$ \\
\hline Day 7 - day $14^{\mathrm{d}}$ & 130 & 108 & 138 & 111 & 29.8 & 0.32 & 0.65 & 0.30 \\
\hline Day 14 - day $21^{\mathrm{d}}$ & 278 & 251 & 303 & 248 & 35.4 & 0.46 & 0.75 & 0.12 \\
\hline Post-challenge (day 8 - day 21$)^{\text {d }}$ & 204 & 179 & 220 & 179 & 29.1 & 0.27 & 0.63 & 0.09 \\
\hline Total (day 0 - day 21) ${ }^{d}$ & 129 & 99 & 156 & 109 & 28.3 & 0.51 & 0.60 & 0.10 \\
\hline \multicolumn{9}{|l|}{ Average daily feed intake, g/d } \\
\hline Day 0 - day $7^{c}$ & 162 & 163 & 200 & 146 & 15.6 & 0.70 & 0.34 & $<0.001$ \\
\hline Day 7 - day $14^{d}$ & 308 & 254 & 376 & 318 & 46.8 & 0.78 & 0.27 & 0.32 \\
\hline Day 14 - day $21^{d}$ & 535 & 532 & 612 & 519 & 47.1 & 0.75 & 0.71 & 0.07 \\
\hline Post-challenge (day 8 - day 21) ${ }^{d}$ & 421 & 393 & 494 & 418 & 44.6 & 0.99 & 0.65 & 0.11 \\
\hline Total (day 0 - day 21) ${ }^{d}$ & 329 & 318 & 396 & 330 & 33.3 & 0.82 & 0.72 & 0.06 \\
\hline \multicolumn{9}{|l|}{ Gain to feed } \\
\hline Day 0 - day $7^{c}$ & -0.52 & -0.38 & 0.19 & -0.56 & 0.19 & 0.62 & 0.76 & $<0.001$ \\
\hline Day 7 - day $14^{d}$ & 0.38 & 0.37 & 0.23 & 0.34 & 0.11 & 0.54 & 0.61 & 0.57 \\
\hline Day 14 - day $21^{\text {d }}$ & 0.51 & 0.46 & 0.49 & 0.47 & 0.03 & 0.35 & 0.93 & 0.39 \\
\hline Post-challenge (day 8 - day 21) d & 0.46 & 0.44 & 0.44 & 0.42 & 0.03 & 0.06 & 0.11 & 0.22 \\
\hline Total (day 0 - day 21) d & 0.36 & 0.28 & 0.38 & 0.30 & 0.05 & 0.22 & 0.74 & 0.20 \\
\hline
\end{tabular}

aAA B. amyloliquefaciens DSM25840, BAS B. subtilis DSM25841, AB Antibiotic, CO Control

${ }^{b}$ Number of animals was 16 for BAA, BAS and CO groups; 15 for $A B$ group

cNumber of animals was: 14 for BAA; 15 for BAS, $A B$ and $C O$.

${ }^{d}$ Number of animals was: 6 for BAA; 9 for BAS; 10 for $A B ; 6$ for $C O$ 
observed in the BAA group than in the $\mathrm{CO}$ group for post-challenge ( $\mathrm{d} 8-\mathrm{d} 21)$ period $(P=0.06)$.

\section{Plasma targeted metabolomics}

The MS/MS targeted analysis provided the quantification of 138 metabolites (Additional file 1: Table S1 SS1). Significantly different metabolites in the blood plasma at d 8 and d 21 are reported in Table 4. At d 8 the BAA group showed lower concentration of arginine [adjiusted $\left.P\left(P_{\text {adj }}\right)=0.02\right]$, lysine $\left(P_{\text {adj }}=0.03\right)$ and ornitine $\left(P_{\text {adj }}=\right.$ $0.04)$ and a trend of lower concentration of threonine $\left(P_{\text {adj }}=0.06\right)$, histamine $\left(P_{\text {adj }}=0.07\right)$ and glycine $\left(P_{\text {adj }}=\right.$ $0.08)$ than $\mathrm{CO}$ group. The BAS group showed lower concentration of lysine $\left(P_{\text {adj }}=0.03\right)$, glycine $\left(P_{\text {adj }}=0.02\right)$, serine $\left(P_{\text {adj }}=0.05\right)$ and P.aa.C30.0 $\left(P_{\text {adj }}=0.05\right)$, and a trend for lower concentration of proline $\left(P_{\text {adj }}=0.07\right)$ than $\mathrm{CO}$ group did on plasma at $\mathrm{d} 8$. The $\mathrm{AB}$ group had a lower concentration of arginine $\left(P_{\text {adj }}=0.02\right)$, lysine $\left(P_{\text {adj }}=0.02\right)$ and threonine $\left(P_{\text {adj }}=0.05\right)$ than $\mathrm{CO}$ group did on plasma at $\mathrm{d} 8$.

At d 21, the BAA group had a higher concentration of glycine $\left(P_{\text {adj }}=0.04\right)$ and glutamine $\left(P_{\text {adj }}=0.05\right)$ and a trend for a higher concentration of serine and a lower concentration of SDMA $\left(P_{\text {adj }}=0.07\right)$ than CO group did.

\section{Serum immunoglobulins and acute phase proteins}

Table 5 reports the results for serum IgA, IgG and IgM at d 6, d 12 and d 21. At d 6, the BAA group had a higher
IgM concentration $(P=0.04)$ and a trend of higher IgG concentration $(P<0.01)$ compared to CO. At d 12 , no differences in serum Igs were observed among groups. At $d$ 21, the BAS group had a higher IgA concentration than CO group did $(P=0.04)$. For the acute phase proteins, no differences in SAA and CRP levels were reported among groups at $\mathrm{d} 8$. For $\mathrm{Hp}$, the $\mathrm{CO}$ group had a higher serum Hp level than the $\mathrm{AB}$ group $(P=0.05 ; 4.50 \mathrm{mg} / \mathrm{mL}$ in $\mathrm{CO}$ and $3.20 \mathrm{mg} / \mathrm{mL}$ in $\mathrm{AB}$ ).

\section{Microbiota profile}

For the jejunum, a total of 502,700 quality checked reads were obtained, which returned a total of 475 different OTUs, distributed among the samples as shown in Additional file 2: Table S2 SS2. For the cecum, a total of 778,626 quality-checked reads were obtained, which returned a total of 1,179 different OTUs, distributed among the samples (Table SS2).

No significant effects of treatment were observed for the Shannon and Chao indices both in jejunum and in cecum. For Beta diversity (Bray-Curtis distance), the Adonis test showed no differences for BAA, BAS and $\mathrm{AB}$ compared to $\mathrm{CO}$. The Non-Metric Multidimensional Scaling (NMDS) plot, performed on Bray-Curtis distance matrix, showed no defined cluster due to treatments (Additional file 3: Figure S1).

The jejunum was dominated by Lactobacillaceae $(63 \%$ of relative abundance) followed by Streptococcaceae

Table 4 Effect of dietary supplementation of Bacillus amyloliquefaciens DSM25840 and Bacillus subtilis DSM25841 on the blood plasma metabolites showing statistical significances in weaned piglets challenged with Escherichia coli F4ac

\begin{tabular}{|c|c|c|c|c|c|c|c|c|}
\hline \multirow{2}{*}{$\begin{array}{l}\text { Metabolite, } \\
\mu \mathrm{mol} / \mathrm{L}\end{array}$} & \multicolumn{4}{|c|}{ Treatments $^{a}$} & \multirow[t]{2}{*}{ SEM } & \multicolumn{3}{|l|}{$P$-value } \\
\hline & BAA & BAS & $A B$ & $\mathrm{CO}$ & & BAA vs. CO & BAS vs. CO & $A B$ vs. $C O$ \\
\hline \multicolumn{9}{|l|}{ Day $8^{b}$} \\
\hline Arg & 107.0 & 117.1 & 105.2 & 145.3 & 16.8 & 0.02 & 0.11 & 0.02 \\
\hline Gly & 657.3 & 597 & 785.7 & 893.7 & 72.3 & 0.08 & 0.02 & 0.64 \\
\hline Lys & 191.5 & 225.7 & 188.3 & 246.3 & 19.3 & 0.03 & 0.03 & 0.02 \\
\hline Orn & 58.0 & 65.4 & 63.8 & 82.9 & 11.0 & 0.04 & 0.19 & 0.14 \\
\hline Pro & 228.5 & 216.5 & 242.5 & 292.6 & 23.6 & 0.14 & 0.07 & 0.31 \\
\hline Ser & 111.1 & 101.7 & 116.4 & 133.1 & 6.8 & 0.22 & 0.05 & 0.44 \\
\hline Thr & 91.1 & 123.5 & 78.1 & 180.4 & 28.0 & 0.1 & 0.41 & 0.05 \\
\hline Tyr & 51.2 & 57.8 & 53.1 & 69.4 & 5.0 & 0.06 & 0.34 & 0.11 \\
\hline Histamine & 153.4 & 73.1 & 81.5 & 73.4 & 12.5 & 0.07 & 0.85 & 0.98 \\
\hline PC.aa.C30.0 & 1.2 & 1.1 & 1.4 & 1.4 & 0.1 & 0.27 & 0.05 & 0.93 \\
\hline \multicolumn{9}{|l|}{ Day $21^{c}$} \\
\hline Gly & 1058 & 927.8 & 910.1 & 791.2 & 55.8 & 0.04 & 0.39 & 0.5 \\
\hline Gln & 551 & 482.6 & 502.3 & 454.7 & 25.8 & 0.05 & 0.82 & 0.46 \\
\hline Ser & 154.7 & 138.9 & 143.7 & 113.6 & 9.9 & 0.07 & 0.31 & 0.18 \\
\hline SDMA & 0.7 & 1.0 & 0.9 & 1.3 & 0.2 & 0.07 & 0.51 & 0.22 \\
\hline
\end{tabular}

${ }^{a}$ BAA B. amyloliquefaciens DSM25840, BAS B. subtilis DSM25841, AB Antibiotic, CO Control

${ }^{b}$ Number of included animals was: 14 for $B A A ; 15$ for $B A S, A B$ and $C O$.

c Number of included animals was: 6 for $B A A ; 9$ for $B A S ; 10$ for $A B ; 6$ for $C O$ 
Table 5 Effect of dietary supplementation of Bacillus amyloliquefaciens DSM25840 and Bacillus subtilis DSM25841 on the blood serum IgA, IgG and IgM of weaned piglets challenged with Escherichia coli F4ac

\begin{tabular}{|c|c|c|c|c|c|c|c|c|}
\hline \multirow[t]{2}{*}{ lgs } & \multicolumn{4}{|c|}{ Treatments $^{a}$} & \multirow[t]{2}{*}{ SEM } & \multicolumn{3}{|l|}{$P$-value } \\
\hline & BAA & BAS & $A B$ & $\mathrm{CO}$ & & BAA vs. CO & BAS vs. CO & $A B$ vs. $C O$ \\
\hline \multicolumn{9}{|c|}{ Day $6, \mathrm{mg} / \mathrm{mL}^{\mathrm{b}}$} \\
\hline $\lg A$ & 0.41 & 0.46 & 0.37 & 0.49 & 0.10 & 0.84 & 0.98 & 0.63 \\
\hline $\lg G$ & 19.80 & 13.72 & 13.92 & 13.54 & 2.61 & 0.09 & 0.96 & 0.91 \\
\hline $\lg M$ & 3.88 & 2.85 & 2.84 & 3.06 & 0.28 & 0.04 & 0.59 & 0.55 \\
\hline \multicolumn{9}{|c|}{ Day $12, \mathrm{mg} / \mathrm{mL}^{\mathrm{c}}$} \\
\hline $\lg A$ & 0.72 & 0.46 & 0.42 & 0.54 & 0.09 & 0.51 & 0.85 & \\
\hline $\lg G$ & 17.94 & 13.6 & 12.57 & 15.84 & 2.24 & 0.55 & 0.48 & 0.31 \\
\hline $\lg M$ & 3.75 & 3.96 & 3.03 & 3.38 & 0.54 & 0.66 & 0.45 & 0.64 \\
\hline \multicolumn{9}{|c|}{ Day $21, \mathrm{mg} / \mathrm{mL}^{\mathrm{d}}$} \\
\hline $\lg A$ & 0.72 & 0.96 & 0.65 & 0.68 & 0.08 & 0.92 & 0.04 & 0.98 \\
\hline $\lg G$ & 10.57 & 11.58 & 11.88 & 12.14 & 1.35 & 0.45 & 0.71 & 0.89 \\
\hline $\lg M$ & 2.86 & 3.25 & 2.75 & 2.82 & 0.32 & 0.93 & 0.34 & 0.88 \\
\hline
\end{tabular}

aAA B. amyloliquefaciens DSM25840, BAS B. subtilis DSM25841, AB Antibiotic, CO Control

${ }^{b}$ Number of animals was 16 for $B A A, B A S$ and $C O$ groups; 15 for $A B$ group

'Number of animals was: 14 for BAA; 15 for BAS, $A B$ and $C O$.

${ }^{\mathrm{d}}$ Number of animals was: 6 for BAA; 9 for BAS; 10 for $A B ; 6$ for $C O$

(14\%) and Clostridiaceae (9\%) families. Dominant families in cecum were Lactobacillaceae (23\%), Prevotellaceae (21\%) and Ruminococcaceae (19\%), followed by Veillonellaceae (10\%) and Lachnospiraceae (9\%). Table 6 reports the results of Kruskal-Wallis test on microbial families of jejunum and cecum (only the Family with $P$ value $<0.05$ ). No significant difference was observed in the jejunum. In cecum, a trend of higher abundance for the Enterobacteriaceae family was identified in $\mathrm{CO}$ compared to BAA, BAS and $\mathrm{AB}\left(P_{\mathrm{adj}}=0.06\right)$.

At genus level, the jejunum was dominated by Lactobacillus (61\%) followed by Streptococcus (12\%), Sarcina (19\%) and Actinobacillus (1.50\%) genera. Dominant genera in cecum were Lactobacillus (23\%), Prevotella (21\%), unclassified_Ruminococcaceae (12\%) followed by
Faecalibacterium (4.7\%) and unclassified_Lachnospiraceae (4.5\%). No significant different genera were observed between groups in jejunum and cecum.

\section{Transcriptomic profile}

To discriminate specific effects of probiotic treatments, the enrichment gene set analysis based on Hallmark genes was performed. Tables 7, 8 and 9 show the most significantly enriched gene sets (FDR $q$-values $\leq 0.05$ ) obtained by the comparison of $\mathrm{CO}$ group to BAA, BAS and $A B$ groups, respectively.

The comparison between BAA and $\mathrm{CO}$ groups showed 40 gene sets significantly enriched for the BAA group and 200 gene sets enriched for the $\mathrm{CO}$ group (FDR $\%<25$ and $P$-values of $\mathrm{NES}<0.05$ ). In

Table 6 Effect of the dietary supplementations of Bacillus amyloliquefaciens DSM25840 and Bacillus subtilis DSM25841 on abundance of microbial families of weaned piglet 14 days after the Escherichia coli F4ac challenge

\begin{tabular}{|c|c|c|c|c|c|c|c|}
\hline \multirow[t]{2}{*}{ Family } & \multicolumn{4}{|c|}{ Treatments $^{a}$} & \multirow[t]{2}{*}{ SEM } & \multirow[t]{2}{*}{$P$-value } & \multirow[t]{2}{*}{ FDR, $P$-value } \\
\hline & BAA & BAS & $A B$ & $\mathrm{CO}$ & & & \\
\hline \multicolumn{8}{|l|}{ Jejunum } \\
\hline Pasteurellaceae & 1.53 & 1.07 & 0.01 & 13.62 & 0.12 & 0.024 & 1.189 \\
\hline Succinivibrionaceae & 0.00 & 0.00 & 0.00 & 0.01 & 0.00 & 0.115 & 2.827 \\
\hline Moraxellaceae & 0.00 & 0.00 & 0.00 & 0.02 & 0.00 & 0.135 & 2.199 \\
\hline \multicolumn{8}{|l|}{ Cecum } \\
\hline Enterobacteriaceae & 0.14 & 0.38 & 0.01 & 1.05 & 0.03 & 0.001 & 0.058 \\
\hline Ruminococcaceae & 8.20 & 21.82 & 20.96 & 24.43 & 0.09 & 0.011 & 0.273 \\
\hline Peptostreptococcaceae & 0.02 & 0.05 & 0.10 & 0.25 & 0.01 & 0.013 & 0.213 \\
\hline
\end{tabular}

BAA B. amyloliquefaciens DSM25840, BAS B. subtilis DSM25841, AB Antibiotic, CO Control. Data are reported as mean of relative abundance \% 
Table 7 Effect of the dietary supplementations of Bacillus amyloliquefaciens DSM25840 on the transcriptomic profile of jejunum mucosa of weaned piglet 14 days after the Escherichia coli F4ac challenge

\begin{tabular}{|c|c|c|c|c|}
\hline Name of the enriched gene set & Size, No. of genes & NES & $P$-value & FDR, $a$ \\
\hline \multicolumn{5}{|l|}{ Gene sets enriched in BAA respect to $\mathrm{CO}^{\mathrm{a}}$} \\
\hline STRUCTURAL_CONSTITUENT_OF_RIBOSOME & 56 & 2.69 & $<0.001$ & $<0.001$ \\
\hline MITOCHONDRIAL_MEMBRANE_PART & 40 & 2.22 & $<0.001$ & $<0.001$ \\
\hline MITOCHONDRIAL_RESPIRATORY_CHAIN & 19 & 2.11 & $<0.001$ & 0.01 \\
\hline RIBOSOME & 25 & 2.08 & $<0.001$ & 0.01 \\
\hline MITOCHONDRIAL_INNER_MEMBRANE & 51 & 2.02 & $<0.001$ & 0.02 \\
\hline \multicolumn{5}{|l|}{ Gene sets enriched in $C O$ respect to $B A A^{a}$} \\
\hline EXONUCLEASE_ACTIVITY & 15 & -2.20 & $<0.001$ & $<0.001$ \\
\hline EXTRACELLULAR_MATRIX_PART & 42 & -2.20 & $<0.001$ & $<0.001$ \\
\hline HELICASE_ACTIVITY & 43 & -2.20 & $<0.001$ & $<0.001$ \\
\hline PROTEINACEOUS_EXTRACELLULAR_MATRIX & 74 & -2.10 & $<0.001$ & $<0.001$ \\
\hline EXTRACELLULAR_MATRIX & 75 & -2.10 & $<0.001$ & $<0.001$ \\
\hline DNA_HELICASE_ACTIVITY & 23 & -2.10 & $<0.001$ & $<0.001$ \\
\hline MEIOTIC_CELL_CYCLE & 29 & -2.00 & $<0.001$ & $<0.001$ \\
\hline LIGASE_ACTIVITY & 82 & -2.00 & $<0.001$ & $<0.001$ \\
\hline CELL_CYCLE_PHASE & 136 & -2.00 & $<0.001$ & 0.01 \\
\hline DNA_REPAIR & 105 & -2.00 & $<0.001$ & 0.01 \\
\hline $\begin{array}{l}\text { TRANSMEMBRANE_RECEPTOR_PROTEIN_TYROSINE } \\
\text { _KINASE_ACTIVITY }\end{array}$ & 39 & -2.00 & $<0.001$ & 0.01 \\
\hline CHROMATIN_BINDING & 26 & -2.00 & $<0.001$ & 0.01 \\
\hline CELL_CYCLE_PROCESS & 154 & -2.00 & $<0.001$ & 0.01 \\
\hline DNA_DEPENDENT_DNA_REPLICATION & 43 & -2.00 & $<0.001$ & 0.01 \\
\hline M_PHASE & 95 & -2.00 & $<0.001$ & $<0.001$ \\
\hline COLLAGEN & 17 & -2.00 & 0.002 & $<0.001$ \\
\hline BASEMENT_MEMBRANE & 28 & -2.00 & $<0.001$ & 0.01 \\
\hline $\begin{array}{l}\text { TRANSMEMBRANE_RECEPTOR_PROTEIN } \\
\text { _KINASE_ACTIVITY }\end{array}$ & 47 & -2.00 & $<0.001$ & 0.01 \\
\hline RESPONSE_TO_DNA_DAMAGE_STIMULUS & 135 & -1.90 & $<0.001$ & 0.01 \\
\hline DNA_REPLICATION & 69 & -1.90 & $<0.001$ & 0.01 \\
\hline
\end{tabular}

${ }^{\mathrm{a} B A A}$ B. amyloliquefaciens DSM25840, CO Control

the BAA group, gene sets related to cell energy metabolism including mitochondrial (MITOCHONDRIAL_MEMBRANE_PART, MITOCHONDRIAL_RE SPIRATORY_CHAIN and MITOCHONDRIAL_INNE R_MEMBRANE), and ribosomal (STRUCTURAL_CO NSTITUENT_OF_RIBOSOME and RIBOSOME) activity were enriched; while the $\mathrm{CO}$ group showed enriched gene set related to cell proliferation, DNA and RNA activities (EXONUCLEASE_ACTIVITY, HE LICASE_ACTIVITY, MEIOTIC_CELL_CYCLE, CELL_C YCLE_PHASE, DNA_REPAIR, CELL_CYCLE_PROCESS) (Table 7).

The comparison between BAS and CO groups showed 131 gene sets significantly enriched for the BAA group and 303 gene sets enriched for the CO group (FDR \% $<25$ and $P$-values of NES $<0.05)$. In the BAS group, enriched gene sets involved cell signalling (RHODOPSIN_LIKE_ RECEPTOR_ACTIVITY, CELL_CELL_SIGNALING, SUB STRATE_SPECIFIC_CHANNEL_ACTIVITY, G_PROTEI N_COUPLED_RECEPTOR_ACTIVITY, G_PROTEIN_SI GNALING_COUPLED_TO_CYCLIC_NUCLEOTIDE_SE COND_MESSENGER) and cell transporters (MONOVALENT_INORGANIC_CATION_TRANSPORT, SODIUM _ION_TRANSPORT, CATION_CHANNEL_ACTIVITY, ION_CHANNEL_ACTIVITY) ranked the top; while the $\mathrm{CO}$ group showed enriched gene set related to cell proliferation, mitotic and meiotic functions (MICROTUBULE_ ORGANIZING_CENTER, CENTROSOME, MITOSIS) (Table 8).

The comparison between $\mathrm{AB}$ and $\mathrm{CO}$ groups showed 141 gene sets significantly enriched for the $A B$ group and 53 gene sets enriched for the $C O$ 
Table 8 Effect of the dietary supplementations of Bacillus subtilis DSM25841 on the transcriptomic profile of jejunum mucosa of weaned piglet 14 days after the Escherichia coli F4ac challenge

\begin{tabular}{|c|c|c|c|c|}
\hline Name of the enriched gene set & Size, No. of genes & NES & $P$-value & FDR, 9 \\
\hline \multicolumn{5}{|l|}{ Gene sets enriched in BAS respect to $\mathrm{CO}^{\mathrm{a}}$} \\
\hline RHODOPSIN_LIKE_RECEPTOR_ACTIVITY & 97 & 2.66 & $<0.001$ & $<0.001$ \\
\hline MONOVALENT_INORGANIC_CATION_TRANSPORT & 72 & 2.49 & $<0.001$ & $<0.001$ \\
\hline SODIUM_ION_TRANSPORT & 17 & 2.43 & $<0.001$ & $<0.001$ \\
\hline CELL_CELL_SIGNALING & 309 & 2.4 & $<0.001$ & $<0.001$ \\
\hline CATION_CHANNEL_ACTIVITY & 90 & 2.37 & $<0.001$ & $<0.001$ \\
\hline SUBSTRATE_SPECIFIC_CHANNEL_ACTIVITY & 119 & 2.3 & $<0.001$ & $<0.001$ \\
\hline ION_CHANNEL_ACTIVITY & 112 & 2.27 & $<0.001$ & $<0.001$ \\
\hline G_PROTEIN_COUPLED_RECEPTOR_ACTIVITY & 140 & 2.25 & $<0.001$ & $<0.001$ \\
\hline HORMONE_ACTIVITY & 35 & 2.2 & $<0.001$ & 0.01 \\
\hline RESPONSE_TO_BACTERIUM & 22 & 2.19 & $<0.001$ & 0.01 \\
\hline CYCLIC_NUCLEOTIDE_MEDIATED_SIGNALING & 81 & 2.17 & $<0.001$ & 0.01 \\
\hline PEPTIDE_RECEPTOR_ACTIVITY & 36 & 2.16 & $<0.001$ & 0.01 \\
\hline G_PROTEIN_SIGNALING_COUPLED_TO_CYCLIC_NUCLEOTIDE_SECOND_MESSENGER & 79 & 2.14 & $<0.001$ & 0.01 \\
\hline VOLTAGE_GATED_CATION_CHANNEL_ACTIVITY & 52 & 2.13 & $<0.001$ & 0.01 \\
\hline INORGANIC_ANION_TRANSPORT & 16 & 2.13 & 0.005 & 0.01 \\
\hline GATED_CHANNEL_ACTIVITY & 95 & 2.12 & $<0.001$ & 0.01 \\
\hline POTASSIUM_ION_TRANSPORT & 45 & 2.11 & $<0.001$ & 0.01 \\
\hline VOLTAGE_GATED_POTASSIUM_CHANNEL_COMPLEX & 32 & 2.08 & $<0.001$ & 0.01 \\
\hline G_PROTEIN_SIGNALING_COUPLED_TO_CAMP_NUCLEOTIDE_SECOND_MESSENGER & 51 & 2.08 & $<0.001$ & 0.01 \\
\hline CATION_TRANSPORT & 119 & 2.07 & $<0.001$ & 0.01 \\
\hline \multicolumn{5}{|l|}{ Gene sets enriched in $\mathrm{CO}$ respect to $\mathrm{BAS}^{\mathrm{a}}$} \\
\hline MICROTUBULE_ORGANIZING_CENTER & 47 & -2.2 & $<0.001$ & $<0.001$ \\
\hline CENTROSOME & 39 & -2.2 & $<0.001$ & $<0.001$ \\
\hline MRNA_METABOLIC_PROCESS & 55 & -2.1 & $<0.001$ & $<0.001$ \\
\hline LIGASE_ACTIVITY_FORMING_CARBON_NITROGEN_BONDS & 56 & -2.1 & $<0.001$ & $<0.001$ \\
\hline NUCLEOPLASM & 227 & -2.1 & $<0.001$ & $<0.001$ \\
\hline ACID_AMINO_ACID_LIGASE_ACTIVITY & 46 & -2.1 & $<0.001$ & $<0.001$ \\
\hline MICROTUBULE_CYTOSKELETON & 110 & -2.1 & $<0.001$ & $<0.001$ \\
\hline LIGASE_ACTIVITY & 82 & -2 & $<0.001$ & $<0.001$ \\
\hline NUCLEOPLASM_PART & 170 & -2 & $<0.001$ & $<0.001$ \\
\hline RNA_PROCESSING & 125 & -2 & $<0.001$ & $<0.001$ \\
\hline DNA_DIRECTED_RNA_POLYMERASEII_HOLOENZYME & 51 & -2 & $<0.001$ & $<0.001$ \\
\hline SMALL_CONJUGATING_PROTEIN_LIGASE_ACTIVITY & 40 & -2 & $<0.001$ & $<0.001$ \\
\hline MITOSIS & 68 & -2 & $<0.001$ & $<0.001$ \\
\hline M_PHASE_OF_MITOTIC_CELL_CYCLE & 71 & -2 & $<0.001$ & $<0.001$ \\
\hline MRNA_PROCESSING_GO_0006397 & 47 & -2 & $<0.001$ & $<0.001$ \\
\hline CHROMOSOMAL_PART & 73 & -2 & $<0.001$ & $<0.001$ \\
\hline CHROMOSOME_ORGANIZATION_AND_BIOGENESIS & 97 & -2 & $<0.001$ & $<0.001$ \\
\hline CHROMOSOME & 94 & -2 & $<0.001$ & $<0.001$ \\
\hline NUCLEAR_LUMEN & 310 & -2 & $<0.001$ & $<0.001$ \\
\hline CELL_CYCLE_PROCESS & 154 & -2 & $<0.001$ & $<0.001$ \\
\hline
\end{tabular}

a BAS B. subtilis DSM25841, CO Control 
Table 9 Effect of the dietary supplementations of antibiotic on the transcriptomic profile of jejunum mucosa of weaned piglet 14 days after the Escherichia coli F4ac challenge

\begin{tabular}{|c|c|c|c|c|}
\hline Name of the enriched gene set & Size, No. of genes & NES & $P$-value & FDR, $q$ \\
\hline \multicolumn{5}{|l|}{ Gene sets enriched in $A B$ respect to $C O^{a}$} \\
\hline LYMPHOCYTE_ACTIVATION & 50 & 2.22 & $<0.001$ & $<0.001$ \\
\hline LEUKOCYTE_ACTIVATION & 56 & 2.2 & $<0.001$ & $<0.001$ \\
\hline IMMUNE_SYSTEM_PROCESS & 260 & 2.17 & $<0.001$ & $<0.001$ \\
\hline IMMUNE_RESPONSE & 182 & 2.3 & $<0.001$ & $<0.001$ \\
\hline CELLULAR_DEFENSE_RESPONSE & 36 & 2.23 & $<0.001$ & $<0.001$ \\
\hline T_CELL_ACTIVATION & 38 & 2.02 & $<0.001$ & $<0.001$ \\
\hline CELL_ACTIVATION & 61 & 2.05 & $<0.001$ & $<0.001$ \\
\hline LYMPHOCYTE_DIFFERENTIATION & 23 & 2.02 & $<0.001$ & $<0.001$ \\
\hline DEFENSE_RESPONSE & 183 & 1.96 & $<0.001$ & 0.01 \\
\hline B_CELL_ACTIVATION & 16 & 1.92 & $<0.001$ & 0.01 \\
\hline REGULATION_OF_IMMUNE_SYSTEM_PROCESS & 53 & 1.88 & $<0.001$ & 0.02 \\
\hline POSITIVE_REGULATION_OF_IMMUNE_SYSTEM_PROCESS & 42 & 1.87 & $<0.001$ & 0.02 \\
\hline HEMOPOIETIC_OR_LYMPHOID_ORGAN_DEVELOPMENT & 67 & 1.86 & $<0.001$ & 0.02 \\
\hline LEUKOCYTE_DIFFERENTIATION & 33 & 1.86 & $<0.001$ & 0.02 \\
\hline INTERLEUKIN_RECEPTOR_ACTIVITY & 17 & 1.84 & 0.003 & 0.03 \\
\hline INTERLEUKIN_BINDING & 22 & 1.82 & 0.003 & 0.03 \\
\hline T_CELL_DIFFERENTIATION & 15 & 1.82 & 0.005 & 0.03 \\
\hline REGULATION_OF_LYMPHOCYTE_ACTIVATION & 30 & 1.82 & $<0.001$ & 0.03 \\
\hline IMMUNE_SYSTEM_DEVELOPMENT & 70 & 1.83 & $<0.001$ & 0.03 \\
\hline PROTEIN_KINASE_CASCADE & 227 & 1.81 & $<0.001$ & 0.03 \\
\hline \multicolumn{5}{|l|}{ Gene sets enriched in $C O$ respect to $A B^{a}$} \\
\hline AMINE_TRANSMEMBRANE_TRANSPORTER_ACTIVITY & 32 & -2.2 & $<0.001$ & 0.01 \\
\hline L_AMINO_ACID_TRANSMEMBRANE_TRANSPORTER_ACTIVITY & 15 & -2 & $<0.001$ & 0.05 \\
\hline CARBOXYLIC_ACID_TRANSMEMBRANE_TRANSPORTER_ACTIVITY & 35 & -2 & $<0.001$ & 0.05 \\
\hline
\end{tabular}

${ }^{\mathrm{a} A B}$ Antibiotic, CO Control

group (FDR $\%<25$ and $P$-values of $\mathrm{NES}<0.05$ ). In the $\mathrm{AB}$ group, gene sets linked with immune response (LYMPHOCYTE_ACTIVATION, LEUKOCYTE_ACTIVATION, IMMUNE_SYSTEM_PROCESS, T and B CELLS ACTIVATION) ranked the top, while in the $\mathrm{CO}$ group several gene sets related to cell transmembrane-transport (AMINE_TRANSMEMBRANE_ TRANSPORTER_ACTIVITY, L_AMINO_ACID_TRANSMEMBRANE_TRANSPORTER_ACTIVITY and CARBOXYLIC_ACID_TRANSMEMBRANE_TRANSPORTER_ ACTIVITY) ranked the top (Table 9).

Overlaps of up and down-regulated gene sets between $\mathrm{BAA}, \mathrm{BAS}$ and $\mathrm{AB}$ compared to $\mathrm{CO}$ are visualized in Venn Plot (Fig. 1). Nine gene sets were commonly up-regulated in BAA, BAS and $\mathrm{AB}$ groups compared to the CO group: LYMPHOCYTE_ACTIVATION, LEUKOCYTE_ACTIVATION, T_CELL_ACTIVATION, LYMPHOCYTE_DIFFERENTIATION, B_CELL_ACTIVATION, T_CELL_DIFFERENTIATION, CELL_STRUCTURE_DISASSEMBLY_DURING_APOPTOSIS, DETEC
TION_OF_EXTERNAL_STIMULUS, DETECTION_OF_ STIMULUS. Five gene set were commonly down-regulated in BAA, BAS and $\mathrm{AB}$ groups compared to the CO group: TRANSMEMBRANE_RECEPTOR_PROTEIN_KINASE_ACTIVITY, TRANSMEMBRANE_RECEPTOR_PROTEIN_TYROSINE_KINASE_ACTIVITY, ENDOMEMBRANE_SYSTEM, CELL_MATRIX_ADHESION, CELL_SUBSTRATE_ADHESION.

\section{Morphometric, histochemical and immunohistochemistry}

No significant differences were observed among the experimental groups for villus and crypt morphology, and for the number of PAS and ALB goblet cells at villus level (Additional file 4: Table S3; SS3). The number of PAS-ALB cells in the crypt was significantly lower in the $\mathrm{AB}$ and BAA groups than in the $\mathrm{CO}$ group (7.42 n./crypt in BAA; 7.42 n./crypt in $\mathrm{AB} ; 8.90 \mathrm{n} . /$ crypt in $\mathrm{CO} ; P=$ $0.05)$, while no difference was observed for the counts of PAS and ALB positive mucin cells (Table SS3). No differences were observed for the apoptotic index and 


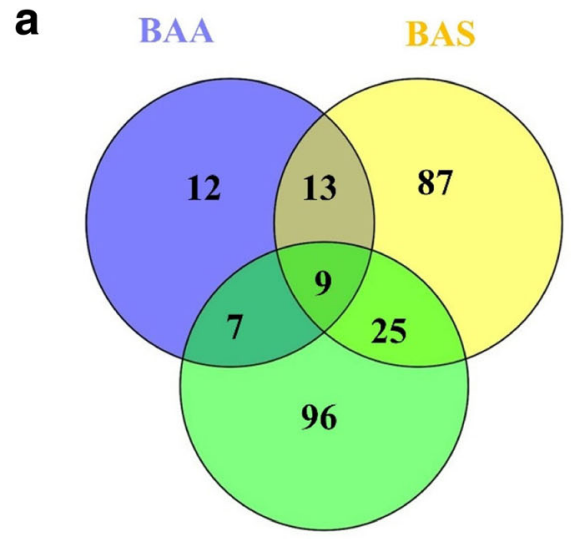

$\mathrm{AB}$

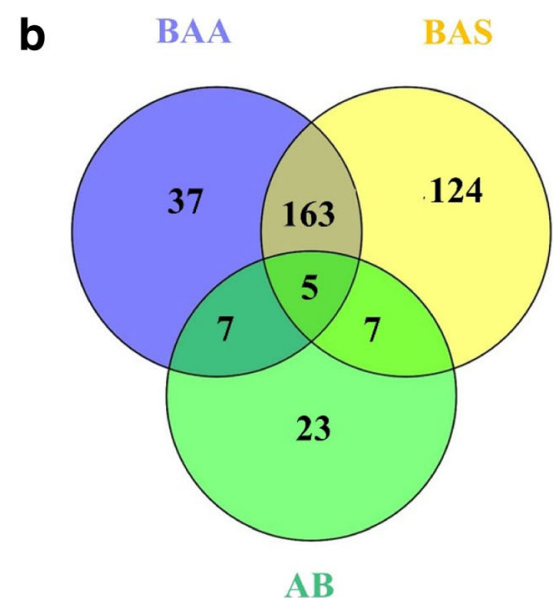

Fig. 1 Numbers of commonly up-regulated (a) and down-regulated $(\mathbf{b})$ gene sets $(F D R<0.25)$ among BAA, BAS and AB groups, compared with the CO group. 9 Gene sets of intersection AB|BAA|BAS were up-regulated: LYMPHOCYTE_ACTIVATION, LEUKOCYTE_ACTIVATION,

T_CELL_ACTIVATION, LYMPHOCYTE_DIFFERENTIATION, B_CELL_ACTIVATION, T_CELL_DIFFERENTIATION,

CELL_STRUCTURE_DISASSEMBLY_DURING_APOPTOSIS, DETECTION_OF_EXTERNAL_STIMULUS, DETECTION_OF_STIMULUS. 5 Gene sets of intersection AB|BAA|BAS: TRANSMEMBRANE_RECEPTOR_PROTEIN_KINASE_ACTIVITY, TRANSMEMBRANE_

RECEPTOR_PROTEIN_TYROSINE_KINASE_ACTIVITY, ENDOMEMBRANE_SYSTEM, CELL_MATRIX_ADHESION, CELL_SUBSTRATE_ADHESION

for the number of IgA positive cells among the experimental groups. The mitotic index in villi of jejunum was lowest in the $\mathrm{CO}$ group than in the BAS and $\mathrm{AB}$ groups respectively $(P=0.01)$, while no difference among groups was observed for the mitotic index in the crypt (Fig. 2).

\section{Discussion}

The present study explores the effect of B. amyloliquefaciens DSM25840 or B. subtilis DSM25841 supplementation in the feed of post-weaning pigs in order to prevent the detrimental effect of ETEC F4ac in subjects genetically susceptible and challenged with this pathogen. A group treated with colistin was used as a positive reference due to the sensitivity of $E$. coli strain used in this trial to this antibiotic [1]. Colistin confirms its capacity to contrast the ETEC F4 infection by reducing the number of piglets excluded from the trial for severe impairment, reducing the piglets' fecal scores and by improving piglet growth performance compared to the CO group. Supplementation with B. subtilis was able to ameliorate the ETEC infection as shown by the reduced fecal scores compared to the $\mathrm{CO}$ group one week after the ETEC infection. Previous observation of $\mathrm{Hu}$ et al. [17] showed that different doses $\left(2 \times 10^{9}\right.$ or $4 \times 10^{9}$ or $20 \times 10^{9} \mathrm{CFU} / \mathrm{kg}$ feed) of $B$. subtilis $\mathrm{KN}-42$ reduced diarrhea index and fecal $E$. coli excretion in non-challenged post-weaning pigs, thus our study confirms that B. subtilis supplementation may reduce diarrhea due to ETEC in post-weaning pigs. On the other hand, B. amyloliquefaciens showed a scarce protective capacity against the ETEC F4ac infection, since no difference in fecal score consistency compared to the $\mathrm{CO}$ group was observed.
From the authors knowledge, few data are published on the effect of $B$. amyloliquefaciens supplementation to counteract the ETEC infection in piglets in vivo. Our results could not confirm the observation of Ji et al. [11] where B. amyloliquefaciens SC06 increased the pro-inflammatory immune response (IL-6, IL-8, TNF- $\alpha$, and $\mathrm{IL}-1 \alpha)$ in an in vitro system based on ETEC challenge. Moreover, in the same work, B. amyloliquefaciens SC06 decreased the diarrhea incidence by $79.2 \%$ in non-infected post-weaning pigs.

In the present study, blood parameters were primarily analysed in order to investigate differences among groups during the acute post-infection phase. A target metabolomics approach was applied to detect metabolic differences and biochemical mechanisms affecting the health status of pigs [35]. Dietary treatments particularly influenced the profile of plasma amino acids, whose concentrations were higher in the $\mathrm{CO}$ group. This general increase of plasma amino acid concentrations in the $\mathrm{CO}$ group, and especially the higher level of lysine, can be explained by a transient increase of catabolic insult leading to muscle breakdown and nitrogen loss as reported by Freund et al. [36] in septiceps patients. Furthermore, according to Rochell et al. [37], we can also hypothesize that plasma amino acids increased as their demand for skeletal muscle synthesis was reduced in $\mathrm{CO}$ group compared to other experimental groups. Indeed, Rochell et al. [37] showed that even if the digestibility of birds infected with Eimeria was decreased compared to the non-infected animals, the plasma amino acids were not decreased homogeneously, suggesting that the level of amino acids in plasma was not directly referred to the 

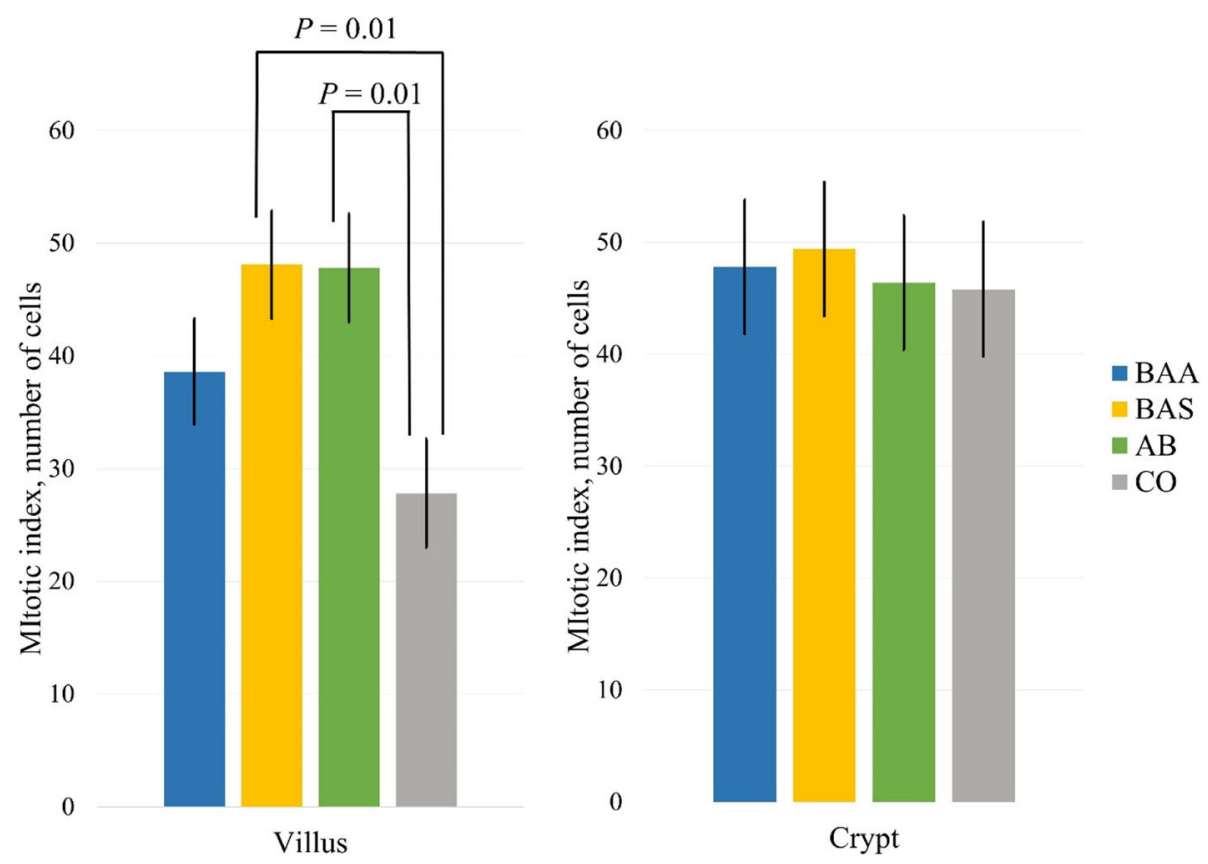

Fig. 2 Effect of the dietary supplementations of Bacillus amyloliquefaciens DSM25840, Bacillus subtilis DSM25841 and antibiotic on jejunal villi and crypt mitotic index of weaned piglets 14 days after the ETEC F4ac challenge. BAS and AB had a higher mitotic index in the jejunal villi than CO $(P=0.01)$. BAA: B. amyloliquefaciens DSM25840; BAS: B. subtilis DSM25841; AB: Antibiotic; CO: Control

absorption and the digestibility while it can be influenced by the skeletal muscle synthesis.

Furthermore, particular attention should be given to the higher level of plasma arginine in the $\mathrm{CO}$ group than in the $\mathrm{AB}$ and the $B$. amyloliquefaciens groups. Arginine is a semi-essential amino acid in pigs and it is an important initiator of immune response as well as a precursor of several metabolic pathways [38]. Particularly it acts as a substrate for enzymatic generation of the antimicrobial molecule nitric oxide (NO), a radical that can inhibit bacterial respiration, DNA replication and modify specific metabolic pathways including the tricarboxylic acid cycle [38]. It can be assumed that the higher level of serum arginine in $\mathrm{CO}$ group could be associated with a lower hepatic degradation through the urea cycle, in order to limit the loss of body nitrogen $(\mathrm{N})$ and the overburden use of essential amino acids [39]. Though, Thomsen et al. [40] showed that in acute phase response the urea cycle enzymes at mRNA levels decreased immediately but gradually returned stable resulting in no change of cycle enzyme proteins, in the present study, it is possible that this preventive control of acute phase condition was not effective in $\mathrm{CO}$ group. Furthermore, arginine turns over rapidly in mammals as inside cells multiple pathways are involved in arginine degradation to produce $\mathrm{NO}$, ornithine, urea, polyamines, proline, glutamate, creatine [41]. In the present study, both ornithine and proline were numerically higher in $\mathrm{CO}$ group with respect to the Bacillus sp. groups, suggesting that, in the $\mathrm{CO}$ group part of arginine was already degraded involving ornithine and proline pathways. Interestingly, a reduced level of glycine and serine was observed in the BAS group which may be associated with the utilization of these amino acids by the B. subtilis strains during sporulation as observed by Mitani and Kadota [42].

In addition to plasma metabolites, the animal health condition was evaluated by analysis of serum acute phase proteins $24 \mathrm{~h}$ after the ETEC infection. CRP, SAA and $\mathrm{Hp}$ are generally considered inflammatory markers; their production by the liver is stimulated by cytokines released from activated phagocytes. In the present study, CRP and SAA were influenced neither by Bacillus administration nor by antibiotic supplementation, however, a previous study suggested that $24 \mathrm{~h}$ post-F4ac ETEC infection could be not sufficient to rise CRP level [5]. On the other hand, $\mathrm{Hp}$ was reduced in the $\mathrm{AB}$ group compared to the CO group, confirming a higher stimulation of inflammatory response in control animals.

In the present study, piglets were then followed until 14 days' post-infection when they recovered from the infection (as confirmed by their reduced fecal score).

Studies suggested that dietary Bacillus spp. supplementation can influence gut microbial profile by promoting the development of beneficial bacteria and by having a competitive action against pathogens as Bacillus spp. can produce a wide variety of antimicrobial compounds $[18,43]$. In the present study, no significant differences in alpha and beta diversity indices were 
observed among groups both in jejunum and in cecum. The presented results are not in accordance with other previous findings in which bacterial communities have been modified by Bacillus spp. supplementation [10, 17, 19]; however, divergent results could be due to different experimental conditions among studies and different microbiota profiles prior to the experiment. Nevertheless, a trend of lower Enterobacteriaceae abundancy in the caecum content was observed both in Bacillus and in AB treatments compared to the $\mathrm{CO}$ group. Enterobacteriaceae family includes both non-pathogenic (commensal bacteria) and pathogens such as ETEC [44]. Among the wide amount of bacteria family present in the gut, Enterobacteriaceae family has been proposed as a non-invasive biomarker of intestinal health [45], since an increase of Enterobacteriaceae has been associated whit intestinal dysbiosis in mice, poultry and weaning pigs [46-48]. It cannot directly be asserted that the probiotics reduced ETEC prevalence, but a reduction in the Enterobacteriaceae abundance could contribute to decreasing the risk of pathogens development, as previously observed for other probiotics such as Lactobacillus (L.) plantarum 4.1 and L. reuteri 3S7 [49] and L. salivarius DPC6005, Pediococcus pentosaceus DPC6006 and L. pentosus DPC6004 [50]. Furthermore, presence and/or differences in abundance of few bacteria in the gut can be sufficient to modify the gene expression regulation in the intestine [51]. In the present study, despite a limited difference in the microbiota profile among groups was observed, it was enough to influence the jejunum transcriptomic profile. The presented results showed that both Bacillus strains and $\mathrm{AB}$ supplementations up-regulated several gene sets related to immune response, including gene sets involved in the stimulus' detection and in adaptive immune response capability (B and $\mathrm{T}$ cells lymphocyte activation). Antibiotic supplementation showed the highest stimulation of gene set for lymphocyte activation and differentiation followed by $B$. subtilis supplementation, while a less intense up-regulation of these gene sets was observed in the B. amyloliquefaciens supplementation group. These results indicate that pigs supplied with Bacillus spp. and antibiotic recovered faster than pigs in the $\mathrm{CO}$ group, which is supported by the finding that the cell mitotic index was improved in jejunum villi in both $A B$ and $B$. subtilis groups.

In addition, compared to antibiotic administration, the supplemented B. subtilis exerted a stimulation on the immune response supported by the observed higher blood IgA level [52], which is consistent with the results of Guo et al. [53].

On the contrary, the $\mathrm{CO}$ group showed a higher stimulation of gene sets related to nuclear structure, RNA processing and of other gene sets related to cell mitosis (microtubule, centrosome) which indicates an improvement of intestinal cells turnover in control animals compared to the other groups and it could be due to a previous higher injury in $\mathrm{CO}$ group [54]. These observations at mRNA level were not traduced into a concrete animal recovery as indicated by the results for blood and immunohistochemistry parameters. Thus, it can be hypothesized that animals in the $\mathrm{CO}$ group had a slower recovery phase compared to pigs in the $A B$ and BAS groups. The slower and reduced recovery capacity of $\mathrm{CO}$ group with respect to both $\mathrm{AB}$ and $\mathrm{BAS}$ groups are also supported by the higher number of animals excluded from the trial for their severe health impartments.

Furthermore, gene sets related to anion, cation, sodium and potassium channel activation, which are all associated with the intestinal absorption and secretion activities [55] were stimulated by $B$. subtilis. The intestinal stimulation of gene sets related to absorption and secretion indicates improved nutrients utilization lending a better feed transformation into body mass and improved animals performance [15]. Thus, the results of the present study support the hypothesis that the probiotic effect of Bacillus strains tested in the present trial can be ascribed to an improvement of feed digestibility by their enzymatic activity [56, 57]. This has also been confirmed by in vitro data showing secretion of NSP-enzymes and proteases by DSM25840 and DSM25841 [8] and by in vivo studies showing improved protein digestibility when these two strains were fed to grower-finisher pigs [58]. Despite an improvement of growth performance in probiotic groups was therefore expected in the present study, this result may be lack because only the most performing pigs were kept in the $\mathrm{CO}$ group. Indeed, a higher number of animals were excluded for severe health impairment in the $\mathrm{CO}$ group compared to the other groups. Thus it cannot be excluded a potential favouring influence of Bacillus spp. on pigs' performance.

\section{Conclusion}

The presented data provide an exhaustive picture on the effectiveness of the tested strain B. subtilis DSM25841 to mitigate the detrimental effect of ETEC F4ac infection in weaned pigs susceptible to this pathogen. B. subtilis promoted the piglet gut health by reducing the Enterobacteriaceae level, favouring the up-regulation of genes related to immunity, contributing in a higher immune competence and in an improvement of the amino acids metabolism and utilization. These are the rationales for favouring the animal post-infection recovery, confirmed by the lower number of pigs with severe diarrhea observed during the study in the treated groups. 


\section{Additional files}

Additional file 1: Table S1. List of the quantified metabolites using the MS/MS targeted analysis. (CSV $18 \mathrm{~kb}$ )

Additional file 2: Table S2. List of number of Observed OTUs, Shannon index and number of reads in jujunum and cecum samples. (DOCX 34 kb)

Additional file 3: Figure S1. Non-Metric Multidimensional Scaling (NMDS) plot on Bray-Curtis distance matrix in jejunum and cecum of ETEC F4-infected pigs fed supplementations of Bacillus amyloliquefaciens DSM25840, Bacillus subtilis DSM25841 and antibiotic at d 21. (DOCX $521 \mathrm{~kb}$ )

Additional file 4: Table S3. Effect of the dietary supplementations of Bacillus amyloliquefaciens or Bacillus subtilis, on the jejunum histology and morphology of weaned pigs 14 days post-infection with ETEC F4. (DOCX $39 \mathrm{~kb}$ )

\section{Abbreviations}

ADFI: Average daily feed intake; ADWG: Average daily weight gain; BW: Body weight; CFU: Colony-forming unit; E. coli: Escherichia coli;

ETEC: Enterotoxigenic Escherichia coli; F:G: Feed to gain ratio;

Igs: Immunoglobulins; LAB: Lactic acid bacteria; PWD: Post-weaning diarrhea; PWDS: Post-weaning diarrhea syndrome

\section{Acknowledgements}

This study is based upon work from COST Action FA1401, supported by COST (European Cooperation in Science and Technology).

\section{Authors' contributions}

PT, PB and BKKN conceived and designed the experiment. DL, MB, VM, CS, $P B, A L, G M$ and $P T$ analysed, interpreted the data. $D L, M B, V M, C S, P B$ and $P T$ performed the in vivo trial. FF performed the blood metabolomics analysis. MM performed morphological and immunohistochemistry analysis. Al performed the analysis of blood acute proteins and lgs. DL, PB and PT wrote the manuscript. All authors read and approved the final manuscript.

\section{Funding}

This work was partly financially supported by Chr. Hansen A/S (Denmark).

\section{Availability of data and materials}

All data generated or analysed during this study are included in this published article [and its supplementary information files]. The datasets on microbiota data supporting the conclusions of this article are available in the PiGutNet area of the European Nucleotide Database (ENA) repository with number ERP114115.

\section{Ethics approval and consent to participate}

The procedures complied with the Italian law pertaining to experimental animals and were approved by the Ethic-Scientific Committee for Experiments on Animals of the University of Bologna and the Italian Ministry of Health by the approval number 892/2016-PR.

\section{Consent for publication}

Not applicable

\section{Competing interests}

BKKN, employee of Chr. Hansen, A/S, was involved only in the experimental design and not in the interpretation of the data. All other authors declare that they have no competing interests.

\section{Author details}

${ }^{1}$ Department of Agricultural and Food Sciences, University of Bologna, Viale G. Fanin 46, 40127 Bologna, Italy. ${ }^{2}$ Department of Agricultural, Environmental and Food Sciences, University of Molise, Via F. De Sanctis, Campobasso, Italy. ${ }^{3}$ Istituto Zooprofilattico Sperimentale della Lombardia e dell'Emilia Romagna Bruno Ubertini, V. Bianchi 9, 25124 Brescia, Italy. ${ }^{4}$ Endocrinology Unit and Center for Applied Biomedical Research, Department of Medical and Surgical Sciences, University of Bologna - S.Orsola-Malpighi Hospital, via Massarenti 9, 40138 Bologna, Italy. ${ }^{5}$ Department of Veterinary Medical Sciences, University of Bologna, Via. Tolara di Sopra 50, 40064 Ozzano Emilia, Italy. ${ }^{6} \mathrm{Chr}$. Hansen A/S, Boege Allé 10-12, 2970 Hoersholm, Denmark.
Received: 11 March 2019 Accepted: 11 July 2019

Published online: 12 September 2019

\section{References}

1. Luise D, Lauridsen C, Bosi P, Trevisi P. Methodology and application of Escherichia coli F4 and F18 encoding infection models in post-weaning pigs. J Anim Sci Biotechnol. 2019;10:53.

2. Brousseau J, Talbot G, Beaudoin F, Lauzon K, Roy D, Lessard M. Effects of probiotics Pediococcus acidilactici strain MA18 / 5M and Saccharomyces cerevisiae subsp. boulardii strain SB-CNCM I-1079 on fecal and intestinal microbiota of nursing and weanling piglets. J Anim Sci. 2015;93:5313-26.

3. Cui Z, Wang L, Wei S, Chen Z, Ma X, Zheng C, et al. Effect of yeast Saccharomyces cerevisiae supplementation on serum antioxidant capacity, mucosal slgA secretions and gut microbial populations in weaned piglets. J Integrative Agr. 2017:16:2029-37.

4. Lallès J-P, Bosi P, Smidt H, Stokes CR. Nutritional management of gut health in pigs around weaning. Proc Nutr Soc. 2007;66:260-8.

5. Trevisi P, Latorre R, Priori D, Luise D, Archetti I, Mazzoni M, et al. Effect of feed supplementation with live yeast on the intestinal transcriptome profile of weaning pigs orally challenged with Escherichia coli F4. Animal. 2017;11:33-44.

6. $\quad$ Yang GY, Zhu YH, Zhang W, Zhou D, Zhai CC, Wang JF. Influence of orally fed a select mixture of Bacillus probiotics on intestinal T-cell migration in weaned MUC4 resistant pigs following Escherichia coli challenge. Vet Res. 2016;47:71.

7. Abriouel H, Franz CMAP, Ben Omar N, Galvez A. Diversity and applications of Bacillus bacteriocins. FEMS Microbiol Rev. 2011;35:201-32.

8. Larsen N, Thorsen L, Kpikpi EN, Stuer-Lauridsen B, Cantor MD, Nielsen B, et al. Characterization of Bacillus spp. strains for use as probiotic additives in pig feed. Appl Microbiol Biotechnol. 2014;98:1105-18.

9. Nielsen B, Cantor M, Zentek J. New probiotic Bacillus strains to improve gut health in piglets. Copenhagen: MIFFI; 2018. p. 32.

10. Poulsen AR, Jonge N, De NJL, Ole H, Lauridsen C, Cutting SM, et al. Impact of Bacillus spp. spores and gentamicin on the gastrointestinal microbiota of suckling and newly weaned piglets. PLoS One. 2018;13(11):e0207382.

11. Ji J, Hu S, Zheng M, Du W, Shang Q, Li W. Bacillus amyloliquefaciens SC06 inhibits ETEC-induced pro-inflammatory responses by suppression of MAPK signaling pathways in IPEC-1 cells and diarrhea in weaned piglets. Live Sci. 2013;158:206-14.

12. Wang $Y$, Wu Y, Wang B, Cao X, Fu A, Li Y, et al. Effects of probiotic Bacillus as a substitute for antibiotics on antioxidant capacity and intestinal autophagy of piglets. AMB Express. 2017;7:52.

13. Li Y, Zhang H, Su W, Ying Z, Chen Y, Zhang L, et al. Effects of dietary Bacillus amyloliquefaciens supplementation on growth performance, intestinal morphology, inflammatory response, and microbiota of intra-uterine growth retarded weanling piglets. J Anim Sci Biotechnol. 2018;13:9-22.

14. Michiels J, Possemiers S, Degroote J, Ovyn A, De Smet S, Nakamura N. Feeding Bacillus subtilis C-3102 to sows and suckling piglets and to weaned piglets improves parameters of gut health and feed: gain ratio in weaners. J Anim Sci. 2016;94:135-7.

15. Alexopoulos C, Georgoulakis IE, Tzivara Al, Kritas SK, Siochu A, Kyriakis SC. Field evaluation of the efficacy of a probiotic containing Bacillus licheniformis and Bacillus subtilis spores, on the health status and performance of sows and their litters. J Anim Phy Anim Nutri. 2004:88:381-92.

16. Wang Y, Cho JH, Chen YJ, Yoo JS, Huang Y, Kim HJ, et al. The effect of probiotic BioPlus 2B on growth performance, dry matter and nitrogen digestibility and slurry noxious gas emission in growing pigs. Liv Sci. 2009; 120:35-42.

17. Hu Y, Dun Y, Li S, Zhao S, Peng N, Liang Y. Effects of Bacillus subtilis KN-42 on growth performance, diarrhea and fecal bacterial flora of weaned piglets. Asian-Australas J Anim Sci. 2014;27:1131-40.

18. Maneewan C, Yamauchi K, Thirabunyanon M, Siri S, Mekbungwan A, Thongwittaya N. Development of Bacillus subtilis MP and effective utilization on productivity and microorganisms in feces of suckling piglets. Int J Appl Res Vet Med. 2011:9:382-7.

19. Bhandari SK, Xu B, Nyachoti CM, Giesting DW, Krause DO. Evaluation of alternatives to antibiotics using an Escherichia coli K88+ model of piglet diarrhea: effects on gut microbial ecology. J Ani Sci. 2008;86:836-47.

20. Zhou D, Zhu Y, Zhang W, Wang M, Fan W, Song D, et al. Ora administration of a select mixture of Bacillus probiotics generates $\operatorname{Tr} 1$ cells 
in weaned F4ab/acR - pigs challenged with an F4+ ETECNTEC/EEC strain. Vet Res. 2015:46:95.

21. Jørgensen CB, Cirera S, Anderson SI, Archibald AL, Raudsepp T, Chowdhary $B$, et al. Linkage and comparative mapping of the locus controlling susceptibility towards E. coli F4ab/ac diarrhea in pigs. Cytogenet. Genome Res. 2003;102:157-62.

22. Noblet J, Valancogne A, Tran G, Ajinomoto Eurolysine sas. EvaPig ${ }^{\oplus}[$ [1.0. 1.4]. Computer program (2008) http://www.evapig.com/x-home-en

23. Trevisi P, Colombo M, Priori D, Fontanesi L, Galimberti G, Calò G, Motta V, et al. Comparison of three patterns of feed supplementation with live Saccharomyces cerevisiae yeast on post-weaning diarrhea, health status and blood metabolic profile of susceptible weaning pigs orally challenged with Escherichia coli F4ac. J Ani Sci. 2015;93:2225-33.

24. Luise D, Motta V, Bertocchi M, Salvarani C, Clavenzani P, Fanelli F, et al. Effect of Mucine 4 and Fucosyltransferase 1 genetic variants on gut homoeostasis of growing healthy pigs. J Anim Phy Anim Nutri. 2019;00:1-12.

25. Bosi P, Sarli G, Casini L, De Filippi S, Trevisi P, Mazzoni M, et al. The influence of fat protection of calcium formate on growth and intestinal defence in Escherichia coli K88-challenged weanling pigs. Anim Feed Sci Technol. 2007;139:170-85.

26. Bokulich NA, Subramanian S, Faith JJ, Gevers D, Gordon Jl, Knight R, et al. Quality-filtering vastly improves diversity estimates from Illumina amplicon sequencing. Nat Methods. 2013;10:57-9.

27. Kisielinski K, Willis S, Prescher A, Klosterhalfen B, Schumpelick V. A simple new method to calculate small intestine absorptive surface in the rat. Clin Exp Med. 2002;2:131-5.

28. McManus JFA, Mowry RW. Staining methods: histologic and biochemical. New York: Medical Division, Harper \& Brother; 1960. p. 283-310.

29. Waly N, Gruffydd-Jones TJ, Stokes CR, Day MJ. The distribution of leucocyte subsets in the small intestine of healthy cats. J Comp Pathol. 2001;124:172-82

30. Xia J, Mandal R, Sinelnikov I, Broadhurst D, Wishart DS. MetaboAnalyst 2.0 - a comprehensive server for metabolomic data analysis. Nucleic Acids Res. 2012;40:1-7.

31. McMurdie PJ, Holmes S, Kindt R, Legendre P, O'Hara R. Phyloseq: an R package for reproducible interactive analysis and graphics of microbiome census data. PLoS One. 2013;8:e61217.

32. Dixon P. VEGAN, a package of $R$ functions for community ecology. J Veg Sci. 2003;14:927-30.

33. Subramanian A, Tamayo P, Mootha VK, Mukherjee S, Ebert BL, Gillette MA, et al. Gene set enrichment analysis: a knowledge-based approach for interpreting genome-wide expression profile. Proc Natl Acad Sci. 2005;102:15545-50.

34. Trevisi P, Priori D, Motta V, Luise D, Jansman AJM, Koopmans S, et al. The effects of starter microbiota and the early life feeding of medium chain triglycerides on the gastric transcriptome profile of 2- or 3-week-old cesarean delivered piglets. J Anim Sci Biotechnol. 2017:8:82.

35. Monteiro MS, Carvalho M, Bastos ML, Guedes de Pinho P. Metabolomics analysis for biomarker discovery: advances and challenges. Curr Med Chem. 2013;20(2):257-71

36. Freund HR, Ryan JA, Fischer JE. Amino acid derangements in patients with sepsis: treatment with branched chain amino acid rich infusions. Ann Surg. 1978;188(3):423-30.

37. Rochell SJ, Parsons CM, Dilger RN. Effects of Eimeria acervulina infection severity on growth performance, apparent ileal amino acid digestibility, and plasma concentrations of amino acids, carotenoids, and a 1-acid glycoprotein in broilers. Poult Sci. 2016;95:1573-81.

38. Fang FC. Antimicrobial actions of nitric oxide. Nitric Oxide. 2012;27:S10.

39. Watford M. The urea cycle: teaching intermediary metabolism in a physiological setting. Biochem Mol Biol Educ. 2003;31:289-97.

40. Thomsen KL, Jessen N, Møller AB, Aagaard NK, Grønbæk H, Holst JJ, et al. Regulation of urea synthesis during the acute-phase response in rats. Am J Physiol Gastrointest Liver Physiol. 2013;304:680-6.

41. Wu G, Knabe DA, Kim SW. Arginine nutrition in neonatal pigs. J Nutr. 2004; 134:2783-90.

42. Mitani T, Kadota H. Incorporation of Glycine and serine into sporulating cells of Bacillus subtilis. Agr Biol Chem. 1976;40(4):677-82.

43. Maruta K, Miyazaki H, Tadano Y, Masuda S, Suzuki A, Takahashi H, et al. Effects of Bacillus subtilis C-3102 intake on fecal flora of sows and on diarrhea and mortality rate of their piglets. Anim Sci Technol. 1996;67:403-9.
44. Schierack P, Walk N, Reiter K, Weyrauch KD, Wieler LH. Composition of intestinal Enterobacteriaceae populations of healthy domestic pigs. Microbiology. 2007;153:3830-7.

45. Ducatelle R, Goossens E, De MF, Eeckhaut V, Antonissen G, Haesebrouck F, et al. Biomarkers for monitoring intestinal health in poultry: present status and future perspectives. Vet Res. 2018;49:43.

46. Eeckhaut V, Wang J, Van PA, Haesebrouck F, Joossens M, Falony G, et al. The probiotic Butyricicoccus pullicaecorum reduces feed conversion and protects from potentially harmful intestinal microorganisms and necrotic enteritis in broilers. Front Microbiol. 2016;7:1416.

47. Gresse R, Chaucheyras-durand F, Fleury MA, Van De Wiele T, Forano E, Blanquet-diot S. Gut microbiota dysbiosis in postweaning piglets understanding the keys to health. Trends Microbiol. 2017;25(10):851-73.

48. Hughes ER, Winter MG, Duerkop BA, Santos RL, Hooper LV, Winter SE, et al. Microbial respiration and formate oxidation as metabolic signatures of inflammation-associated dysbiosis. Cell Host Microbe. 2017;21:208-19.

49. De Angelis M, Siragusa S, Caputo L, Ragni A, Burzigotti R, Gobbetti M. Survival and persistence of Lactobacillus plantarum 4.1 and Lactobacillus reuteri 357 in the gastrointestinal tract of pigs. Vet Microbiol. 2007;123:133-44.

50. Gardiner GE, Casey PG, Casey G, Lynch PB, Lawlor PG, Hill C, et al. Relative ability of orally administered lactobacillus murinus to predominate and persist in the porcine gastrointestinal tract. Appl Environ Microbiol. 2004;70:1895-906.

51. Trevisi P, Priori D, Jansman AJM, Luise D, Koopmans S-J, Hynönen U, et al. Molecular networks affected by neonatal microbial colonization in porcine jejunum, luminally perfused with enterotoxigenic Escherichia coli F4ac fimbria or Lactobacillus amylovorus. PLoS One. 2018;13:e0202160.

52. Yeruva L, Spencer NE, Saraf MK, Hennings L, Bowlin AK, Cleves MA, et al. Formula diet alters small intestine morphology, microbial abundance and reduces VE-cadherin and IL-10 expression in neonatal porcine model. BMC Gastroenterol. 2016;16:40.

53. Guo M, Wu F, Hao G, Qi Q, Li R, Li N, et al. Bacillus subtilis improves immunity and disease resistance in rabbits. Front Immunol. 2017;8:254.

54. Doxsey S, Zimmerman W, Mikule K. Centrosome control of the cell cycle. Trends Cell Biol. 2005;15:303-11.

55. Kiela PR, Ghishan FK. Physiology of intestinal absorption and secretion. Best Pract Res Clin Gastroenterol. 2016;30:145-59.

56. Shi C, Zhang Y, Lu Z, Wang Y. Solid-state fermentation of corn-soybean meal mixed feed with Bacillus subtilis and Enterococcus faecium for degrading antinutritional factors and enhancing nutritional value. J Anim Sci Biotechnol. 2017:8:50

57. Upadhaya SD, Kim SC, Valientes RA, Kim IH. The effect of Bacillus-based feed additive on growth performance, nutrient digestibility, fecal gas emission, and pen cleanup characteristics of growing-finishing pigs. Asian-Australas J Anim Sci. 2015:28:999-1005.

58. Blavi L, Jørgensen JN, Stein H. Effects of Bacillus amyloliquefaciens and Bacillus subtilis on ileal digestibility of AA and total tract digestibility of CP and gross energy in diets fed to growing pigs. J Anim Sci. 2018;97(2):727-34

Ready to submit your research? Choose BMC and benefit from

- fast, convenient online submission

- thorough peer review by experienced researchers in your field

- rapid publication on acceptance

- support for research data, including large and complex data types

- gold Open Access which fosters wider collaboration and increased citations

- maximum visibility for your research: over $100 \mathrm{M}$ website views per year

At BMC, research is always in progress.

Learn more biomedcentral.com/submissions 